\title{
1 Evaluation of two lipid removal methods for stable carbon and nitrogen \\ 2 isotope analysis in whale tissue
}

3 Kerri J. Smith ${ }^{1,2^{*}}$, Clive N. Trueman ${ }^{3}$, Christine A. M. France ${ }^{4}$, Markus J. Peterson ${ }^{1}$

$4{ }^{1}$ Department of Biological Sciences, University of Texas at El Paso, El Paso, Texas, United

5 States

$6{ }^{2}$ Department of Vertebrate Zoology, National Museum of Natural History, Washington DC, 7 United States

$8{ }^{3}$ Ocean and Earth Science, University of Southampton, National Oceanography Centre, 9 European Way, Southampton, United Kingdom

$10{ }^{4}$ Museum Conservation Institute, Smithsonian Institution, Suitland, Maryland, United States

11 * Correspondence:

12 Kerri J. Smith

13 smithkerrij@gmail.com

Keywords: carbon, cetacean, lipid removal, nitrogen, stable isotopes

\section{Abstract}

18 RATIONALE

19 The presence of lipids in animal tissues can influence the interpretation of stable isotope data,

20 particularly in lipid-rich tissues such as the skin and muscle of marine mammals. The

21 traditionally employed chloroform:methanol delipidation protocol has the potential to alter $\delta^{15} \mathrm{~N}$

22 values in proteinaceous tissues. Our objective was to determine whether cyclohexane is an

23 alternative extraction method, effectively removing lipids without altering $\delta^{15} \mathrm{~N}$ values.

\section{METHODS}

25 Kidney, liver, muscle, and skin samples were collected from beach-cast Sowerby's beaked

26 whales (Mesoplodon bidens). Control subsamples were processed without delipidation

27 extraction, and duplicate subsamples were extracted with either chloroform:methanol or

28 cyclohexane. $\delta^{13} \mathrm{C}, \delta^{15} \mathrm{~N}$, and $\mathrm{C}: \mathrm{N}$ values were determined by continuous-flow elemental analysis 
29 isotope ratio mass spectrometry. Paired Wilcoxon tests were used to evaluate the change in

30 isotope values after extraction, and unpaired Wilcoxon tests were used to evaluate difference in

31 isotope values between extractions.

\section{RESULTS}

33 Cyclohexane is an effective delipidation technique for tissues with low and moderate lipid

34 content. Chemical delipidation influenced $\delta^{15} \mathrm{~N}$ values; extracted samples generally showed an

35 increase in $\delta^{15} \mathrm{~N}$ values which varied $0.0 \%$ to $1.7 \%$. Chloroform:methanol extraction resulted in

36 alterations to $\delta^{15} \mathrm{~N}$ values greater than analytical precision for all analyzed tissues. Changes to

$37 \quad \delta^{15} \mathrm{~N}$ values after cyclohexane extraction were at or near analytical precision in liver and muscle

38 but greater than analytical precision for kidney and skin.

\section{CONCLUSIONS}

40 We recommend processing duplicate subsamples for stable isotope analysis, one with and one

41 without extraction in order to obtain accurate values for each isotope. Prolonged chemical

42 extractions are not necessary to effectively remove lipids. When samples are limited, we suggest

43 using cyclohexane for tissues with low or moderate lipid content, and chloroform:methanol for

44 higher lipid-rich tissues.

\section{Introduction}

46 Stable isotope analysis (SIA) of animal tissues is a rapidly expanding tool applied to a

47 variety of environmental, ecological, anthropological, and forensic problems; however,

48 interpretation of stable isotope data can be confounded by a suite of variables related to sample

49 design, collection, preparation, and analysis ${ }^{1,2}$. Animal tissues are comprised of multiple

50 compound classes (e.g., proteins) and compounds (e.g., amino acids), each with potentially

51 different isotopic compositions ${ }^{3}$. The isotopic composition of bulk (whole) tissue is an average of 
52 the isotopic composition of the constituent molecules weighted by their relative proportion ${ }^{4,5}$. If

53 the relative proportion of isotopically distinct tissue components varies among bulk samples,

54 then tissue composition will contribute to measured population stable isotope means and

55 distributions. Wildlife and anthropological studies addressing questions of spatial origin,

56 movement behavior, or diet commonly focus on largely proteinaceous tissues such as muscle,

57 feather, hair keratin, or bone collagen for isotopic analyses ${ }^{6,7}$. Such tissues commonly also

58 contain lipids, potentially influencing $\delta^{13} \mathrm{C}$ values and $\mathrm{C}: \mathrm{N}$ ratios ${ }^{8-10}$. On average, synthesized

59 body lipids tend to be depleted in ${ }^{13} \mathrm{C}$ compared to synthesized proteins, so that the presence of

60 lipids within protein samples tends to reduce bulk tissue $\delta^{13} \mathrm{C}$ values. The degree of isotopic

61 differentiation can vary depending on lipid and protein composition, nutritional status, and other

62 physiological effects ${ }^{8,11,12}$. Soft tissues such as muscle, liver, and subcutaneous connective

63 tissues frequently act as physiological lipid stores. Lipid contents in these tissues may be high

64 and markedly variable among individuals ${ }^{13}$. Failure to consider lipid content when conducting

65 tissue-based studies can therefore bias data interpretation and lead to erroneous conclusions

66 about diet or movement patterns ${ }^{9,14,15}$. Two approaches have been proposed to address the

67 problem of lipid content in mixed tissue isotope analyses: statistical isotopic correction models

68 and chemical removal of lipids.

69 Statistical isotopic correction models aim to account for the influence of ${ }^{13} \mathrm{C}$ depleted

70 lipids retrospectively using $\mathrm{C}: \mathrm{N}$ ratios as predictors of lipid content and mass balance approaches

71 to correct measured values ${ }^{16}$. These models typically are established by statistical regression

72 between measured $\delta^{13} \mathrm{C}$ values and $\mathrm{C}: \mathrm{N}$ ratios and may also utilize measured or estimated end

73 member values for pure lipid, pure protein, or expected protein:lipid offsets. The coefficients

74 associated with statistical lipid correction models are likely to vary according to tissue type, 
75 physiology, and metabolic status. Therefore, while a variety of models are available, they do not

76 generate consistent results between and within species and tissue types ${ }^{13,17-20}$. Thus, lipid

77 correction models must be parameterized for each study and may still yield inconsistent results ${ }^{21-}$

$78 \quad 24$.

79 Chemical lipid extraction provides a rapid and consistent means of ensuring lipid

80 removal. The most common method for lipid extraction is a polar solvent solution of

81 chloroform:methanol. This technique, in use for more than 60 years, is effective at removing

82 lipids. However, the process is relatively aggressive, potentially also influencing the relative

83 proportions of amino acids present because of the higher solubility of the polar amino acids in

84 polar solutes ${ }^{9,25}$. As $\delta^{13} \mathrm{C}$ and $\delta^{15} \mathrm{~N}$ values vary among individual amino acids, altering the

85 relative proportions of amino acids present in a protein following chloroform:methanol

86 extractions can alter the isotopic compositions of both carbon and nitrogen in bulk protein

87 analyses. Non-polar solvents, such as hexane and diethyl ether, provide an alternative means of

88 lipid removal. All amino acids are relatively insoluble in non-polar solvents, so the use of non-

89 polar solvents for lipid extraction carries less risk of unintentional alteration of amino acid and

90 bulk protein isotopic compositions ${ }^{11,14}$. Despite years of study and the rise in the use of stable

91 isotope analyses of animal tissues, the relative performance of different chemical extraction

92 approaches as applied to specific tissues of different species is still not well characterized. As a

93 result, there is a conflicting body of evidence about the effects of lipid extraction on $\delta^{13} \mathrm{C}$ and

$94 \delta^{15} \mathrm{~N}$ values and a lack of consistency in extraction methods employed across studies. In addition

95 to avoiding the potential effects of chemical extraction on target protein isotopic compositions, it

96 may be beneficial to avoid chemical extraction for simple time and cost considerations. 
For any given species, tissue, and study there is often uncertainty regarding: (1) whether

98 tissue lipid extraction is a necessary step prior to stable isotope analyses; and if so, (2) the

99 magnitude of undesirable isotopic alteration that should be expected associated with different

100 chemical extraction methods. This is especially problematic in the case of poorly studied species,

101 tissues with few case studies in the literature, and tissues with high and variable lipid contents.

102 In this study we evaluated two methods of lipid removal, chloroform:methanol and 103 cyclohexane, and their effects on $\delta^{13} \mathrm{C}, \delta^{15} \mathrm{~N}$, and $\mathrm{C}: \mathrm{N}$ values in four tissue types collected from

104 Sowerby's beaked whales (Mesoplodon bidens), a rare and elusive species. Cyclohexane is a

105 nonpolar solvent frequently used to extract lipids for lipid research studies but has only

106 occasionally been used in stable isotope analyse ${ }^{26-31}$. Whale tissue, especially skin, is lipid-rich

107 and has proven particularly challenging to evaluate with statistical isotopic correction models

$10813,17,23$. Thus, it is often assumed to be necessary to use a chemical extraction method when

109 processing whale tissue. Here, we assessed the necessity of using a chemical lipid extraction

110 method in tissue for this whale species, the degree to which each method altered isotope ratios,

111 and how any changes to isotope values may influence interpretation of these values.

\section{Materials and Methods}

113 Sampling, sample preparation, and stable isotope analysis

114 We obtained samples of kidney $(n=18)$, liver $(n=17)$, muscle $(n=18)$, and skin $(n=24)$

115 from 26 stranded M. bidens ( $n=77$ total tissue samples). Samples were opportunistically

116 collected from beach-cast carcasses from various locations along the Scottish coastline by the

117 Scottish Marine Animal Stranding Scheme and stored at $-20^{\circ} \mathrm{C}$. We collected $\sim 0.5 \mathrm{~g}$ subsamples

118 of frozen tissues and preserved them in $95 \%$ ethanol for $<1$ week for transport. Ethanol is a

119 commonly used preservative for soft tissues that can contribute to lipid removal and increase 
$120 \quad \delta^{13} \mathrm{C}$ values in the tissues of some species, but typically has small and insignificant effects on

$121 \delta^{15} \mathrm{~N}$ values ${ }^{32-35}$. Prior to analyses we removed excess ethanol, subsampled each tissue sample,

122 freeze dried the samples individually for 16 hours, and ground dried tissues with mortar and

123 pestle. We subsampled 10 samples from each tissue type to serve as an unextracted control; these

124 samples were submitted for stable isotope analysis without lipid extraction. For each of the 77

125 tissue samples, we extracted one subsample with 2:1 chloroform:methanol for 30 minutes,

126 manually agitating samples every 5 minutes. We repeated this process with a duplicate sample

127 for cyclohexane extraction. Lipid extraction timelines vary among studies from minutes to days;

128 we employed a single 30-minute extraction to keep extraction methods consistent between our

129 two protocols. Longer extraction times, particularly for chloroform:methanol, are often

130 employed on tissues ${ }^{8,11,14}$. However, it is unclear if prolonged extraction is necessary to

131 effectively remove lipids, especially on finely ground materials. Lipid extracted samples were

132 dried at $60{ }^{\circ} \mathrm{C}$ for 16 hours post extraction. Between 0.5 and $0.8 \mathrm{mg}$ of each sample was loaded in

$1333 \times 5 \mathrm{~mm}$ tin capsules and submitted for $\mathrm{C}$ and $\mathrm{N}$ stable isotope analysis.

134 Stable isotope analysis was completed at the Smithsonian Institution Museum

135 Conservation Institute Stable Isotope Mass Spectrometry Laboratory using a Thermo Delta V

136 Advantage mass spectrometer in continuous flow mode coupled to an Elementar vario ISOTOPE

137 Cube Elemental Analyzer via a Thermo Conflo IV (ThermoFisher Scientific, 168 Third Avenue

138 Waltham, MA USA 02451). We used V-PDB and Air to calibrate $\delta^{13} \mathrm{C}$ and $\delta^{15} \mathrm{~N}$, respectively.

139 Two standards, an in-house Costech Acetanilide (Costech Analytical, 26074 Avenue Hall, Suite

14014 Valencia, CA USA 91355) and Urea-UIN3, calibrated to USGS40 and USGS41 (L-glutamic

141 acid), were included between every 10 samples to ensure accuracy and precision, with an 
142 analytical precision of $+/-0.2 \%$ o $(1 \sigma)$. Weight percent carbon and nitrogen values were calibrated

143 to the in-house acetanilide standard with an analytical precision of $+/-0.5 \%$.

144 Data analysis

145 Our data analyses addressed four questions: (1) are both lipid removal techniques

146 effective; (2) how much variance is there between chloroform:methanol and cyclohexane

147 extracted samples; (3) does delipidation extraction meaningfully change $\delta^{13} \mathrm{C}, \delta^{15} \mathrm{~N}$, and C:N

148 values; and (4) do extraction methods change isotope values in similar ways? To answer question

149 (1), we evaluated the $\mathrm{C}: \mathrm{N}$ ratios post extraction for all samples $(n=77)$ because he $\mathrm{C}: \mathrm{N}$ ratio

150 often is used to evaluate the presence of lipids in tissue samples, and previous studies have

151 identified a significant relationship between larger $\mathrm{C}: \mathrm{N}$ ratios, higher lipid proportions, and lower

$152 \delta^{13} \mathrm{C}$ values in some animal tissues ${ }^{8}$. We used these same 77 samples to address question (2),

153 employing paired Wilcoxon tests to compare $\delta^{13} \mathrm{C}, \delta^{15} \mathrm{~N}$, and $\mathrm{C}: \mathrm{N}$ values between each

154 subsample of chloroform:methanol and cyclohexane extracted tissue. We then used a subset of

155 these samples ( $n=40 ; 10$ of each tissue type) to address questions 3 and 4 , comparing $\delta^{13} \mathrm{C}$,

$156 \quad \delta^{15} \mathrm{~N}$, and $\mathrm{C}: \mathrm{N}$ values of the unextracted control samples to those same tissues post extraction.

157 We selected these tissues because there was enough of each sample for pre- and post-extraction

158 analysis and duplicate analysis, if needed. To address question (3), we used paired Wilcoxon

159 tests to evaluate differences in pre- and post-extraction values for each extraction method to

160 explore how extraction method changed isotope values $\left(\delta^{13} \mathrm{C}\right.$ and $\left.\delta^{15} \mathrm{~N}\right)$ and their relationship to

161 each other ( $\mathrm{C}: \mathrm{N}$ ratios). For question (4), we used unpaired Wilcoxon tests to compare the degree

162 and direction of change in values between the same tissue subsamples extracted with

163 chloroform:methanol and cyclohexane. We considered $p$-values $\leq 0.05$ significant, and statistical

164 analyses were performed using $\mathrm{R}^{36}$ with RStudio ${ }^{37}$. 
We use two delta notations to express our results. The first is the standard delta notation

$166 \delta$, which is the parts per thousand difference between the sample and international standards,

167 expressed as $\delta^{\mathrm{y}} X=\left[\left(R_{\text {sample }}-R_{\text {standard }}\right) /\left(R_{\text {standard }}\right)\right]$, where $X$ is the element, $y$ is the atomic mass of

168 the stable isotope, and $R$ is the ratio of heavy to light isotopes. The second is $\Delta$ notation, used to

169 represent the difference between two $\delta$ values. In this paper we use it to represent the difference

170 between extracted and unextracted values (e.g. $\Delta^{13} \mathrm{C}=\delta^{13} \mathrm{C}_{\text {extracted }}-\delta^{13} \mathrm{C}_{\text {unextracted}}$ ).

171 Results and Discussion

172 For question (1), we found both extraction methods effectively removed lipids from

173 tissues with relatively lower initial lipid content. A 30-minute chloroform:methanol extraction

174 effectively delipidated lipid-rich tissues, and a 30-minute cyclohexane extraction was

175 moderately effective at delipidating lipid-rich tissues . $\mathrm{C}: \mathrm{N}$ ratios were reduced to $<5$ in all 77

176 chloroform:methanol extracted samples, and in all but 1 cyclohexane extracted skin sample

177 (Figure 1). There is currently no consensus regarding "correct" marine mammal C:N ratios

178 following delipidation; some sources suggest tissues with $\mathrm{C}: \mathrm{N}$ (by mass) values $>3.5$ contain

179 sufficient lipid to significantly complicate tissue $\delta^{13} \mathrm{C}$ interpretations, while others consider

180 values between 4 and 5 acceptable ${ }^{8,13,38}$. Our chloroform:methanol extracted samples had a mean

181 C:N ratio of 3.4 (range: $3.0-4.7$ ), and the cyclohexane extracted mean was 3.6 (range: $3.0-$

182 6.4). Thus, chloroform:methanol $\mathrm{C}: \mathrm{N}$ ratios in this study fell within multiple definitions of

183 acceptable $\mathrm{C}: \mathrm{N}$ ratios, demonstrating that prolonged extraction times, especially on ground

184 tissue, are not necessary. Likewise, cyclohexane $\mathrm{C}: \mathrm{N}$ ratios for most tissues also fell within

185 acceptable $\mathrm{C}: \mathrm{N}$ ratios, and longer extractions with this method may only be required on lipid-rich

186 tissues, such as skin. 
For both extraction methods, mean skin $\mathrm{C}: \mathrm{N}$ values were greater than total sample mean

188 (chloroform:methanol = 3.8; cyclohexane $=4.1$ ), and muscle, liver, and kidney C: $\mathrm{N}$ mean were

189 less than total sample mean (chloroform:methanol=3.2, 3.2, and 3.2 respectively; cyclohexane

$190=3.3,3.4$, and 3.3 respectively) (Figure 1). The observed relationship between $\delta^{13} \mathrm{C}$ values and

191 C:N ratios post extraction begins to level out when $\mathrm{C}: \mathrm{N}$ ratios exceed 4 , and extrapolation of the

192 relationship to infinite $\mathrm{C}: \mathrm{N}$ ratios suggests that the $\delta^{13} \mathrm{C}$ value of pure lipid in Sowerby's beaked

193 whale tissues is between $-20 \%$ and $-25 \%$. Based on the observed relationship between $\delta^{13} \mathrm{C}$

194 values and $\mathrm{C}: \mathrm{N}$ ratios (Figure 1), together with the assumed $\mathrm{C}: \mathrm{N}$ ratio of pure protein ${ }^{8}$, we

195 suggest that beaked whale tissue samples with $\mathrm{C}: \mathrm{N}$ ratios around 3.5 do not require chemical

196 extraction or statistical correction.

197 Paired Wilcoxon tests for question (2), variance between chloroform:methanol and 198 cyclohexane extracted samples $(n=77)$, demonstrated that $\delta^{13} \mathrm{C}$ values of kidney, liver, and skin 199 subsamples extracted with chloroform:methanol were significantly different than subsamples of 200 those same tissues extracted with cyclohexane, and the difference in muscle tissue values 201 approached significance (Table 1). For $\delta^{15} \mathrm{~N}$ values, only kidney subsamples were significantly 202 different between the two extraction methods. The mean differences in $\delta^{15} \mathrm{~N}$ values in kidney, 203 liver, muscle, and skin tissues were $0.5 \%, 0.3 \%, 0.4 \%$, and $0.3 \%$ o respectively, and differences 204 in $\delta^{15} \mathrm{~N}$ between extracted subsamples ranged from $0.0 \%$ to $1.7 \%$. C:N values were significantly 205 different in kidney,liver, and skin subsamples (Table 1).

206 Finally, we addressed questions (3) and (4), evaluating the effect of lipid extraction on 207 isotope values and variation in values between differently extracted subsamples of the same 208 tissue sample. Below we summarize the treatment effects and recommendations for each tissue 209 type: 
210 Kidney

211 Unextracted C:N ratios ranged between 3.2 and 3.7 with a mean of 3.3 and low variation

212 among individuals (Table 2). Chloroform:methanol extraction reduced C:N ratios and decreased

213 mean $\delta^{13} \mathrm{C}$ values. Both extraction methods increased variation among individuals in $\delta^{13} \mathrm{C}$ and

$214 \delta^{15} \mathrm{~N}$ values. Chloroform:methanol extraction resulted in greater variation among individuals for

$215 \Delta^{13} \mathrm{C}$ values, and both extraction methods had similar variation among individuals in $\Delta^{15} \mathrm{~N}$ and

$216 \Delta \mathrm{C}: \mathrm{N}$ values (Table 3, Figure 2). Due to the low $\mathrm{C}: \mathrm{N}$ ratios in unextracted samples and

217 inconsistent changes to among variation among individuals in $\delta^{13} \mathrm{C}$ and $\delta^{15} \mathrm{~N}$ values, we

218 recommend avoiding lipid extraction in whale kidney samples.

219 Liver

220 Unextracted C:N ratios ranged between 3.2 and 4.0 with a mean of 3.4 and a small

221 variation among individuals (Table 2). Chloroform:methanol extraction reduced C: $\mathrm{N}$ ratios and

222 decreased mean $\delta^{13} \mathrm{C}$ values and variation among individuals in $\delta^{13} \mathrm{C}$ values. $\delta^{15} \mathrm{~N}$ values and

223 variation among individuals remained largely unchanged after both extraction methods. Both

224 extraction methods had similar variation among individuals in $\Delta^{13} \mathrm{C}, \Delta^{15} \mathrm{~N}$, and $\Delta \mathrm{C}: \mathrm{N}$ values;

225 however, mean $\Delta \mathrm{C}: \mathrm{N}$ between extraction methods was significantly different (Table 3, Figure 2).

226 Due to low C:N ratios in unextracted tissues, we recommend avoiding lipid extraction in whale

227 liver samples. However, due to the reduction in variation among individuals in $\delta^{13} \mathrm{C}$ values and

228 relatively low effect on $\delta^{15} \mathrm{~N}$ and $\Delta^{15} \mathrm{~N}$ values post extraction, a short extraction with

229 chloroform:methanol may be useful in some studies.

230 Muscle

231 Unextracted C:N ratios ranged between 3.1 and 6.8 with a mean of 3.7 and a large

232 variation among individuals (Table 2). Both extraction methods effectively reduced mean C:N 
233 ratios below 3.5 and reduced among individual variability in $\delta^{13} \mathrm{C}$ values. Both extraction

234 methods increased mean $\delta^{15} \mathrm{~N}$ values to a similar extent, but chloroform:methanol resulted in

235 greater variation among individuals. Chloroform:methanol extraction resulted in greater variation

236 among individuals in $\Delta{ }^{13} \mathrm{C}, \Delta{ }^{15} \mathrm{~N}$, and $\Delta \mathrm{C}: \mathrm{N}$ values (Table 3, Figure 2). We therefore recommend

237 cyclohexane extraction for whale muscle samples.

238 Skin

239 Unextracted C:N ratios ranged between 3.3 and 11.7 with a mean of 6.4 and a large

240 variation among individuals (Table 2). Both extraction methods significantly reduced mean C:N

241 ratios and reduced variation among individuals in $\delta^{13} \mathrm{C}$ values, though variation among

242 individuals post cyclohexane extraction was greater than post chloroform:methanol extraction.

243 Both extraction methods increased mean $\delta^{15} \mathrm{~N}$ values to a similar extent, but

244 chloroform:methanol extraction resulted in increased variation among individuals.

245 Chloroform:methanol extraction resulted in greater variation among individuals for both in $\Delta^{13} \mathrm{C}$

246 and $\Delta \mathrm{C}: \mathrm{N}$ values, whereas cyclohexane extraction resulted in greater variation among individuals

247 in $\Delta^{15} \mathrm{~N}$ values (Table 3, Figure 2). We therefore recommend subsampling whale skin samples

248 and submitting one samples for stable isotope analysis without lipid extraction to obtain an

249 accurate $\delta^{15} \mathrm{~N}$ value, and one after extraction with chloroform:methanol for an accurate $\delta^{13} \mathrm{C}$

250 value.

251 Conclusions and Recommendations

252 Our results indicate that cyclohexane is an effective delipidation technique for tissues

253 with low and moderate lipid content, but not as effective as chloroform:methanol with lipid-rich

254 tissues, such as whale skin. In the sampled Sowerby's beaked whale tissues, the $\delta^{13} \mathrm{C}$ value of

255 lipids is between $-20 \%$ and $-25 \%$, and tissues with lower C:N ratios, such as kidney and liver, 
256 do not require delipidation (Table 2). Samples extracted with cyclohexane resulted in generally

257 lesser changes to $\delta^{15} \mathrm{~N}$ compared to chloroform-methanol extraction, with some differences being

258 at or near analytical precision, suggesting that this extraction method is less likely to alter the

259 abundance of amino acids in the sample.

260 It is possible to aggressively delipidate tissues multiple times to obtain a desired C:N

261 ratio, but increasingly aggressive extractions dramatically increase the risk of altering amino acid

262 compositions and associated bulk protein $\delta^{13} \mathrm{C}$ and $\delta^{15} \mathrm{~N}$ values. We found that a single 30-

263 minute extraction effectively removed lipids in most tissue samples, suggesting that prolonged

264 lipid extraction of hours or days may be unnecessary, especially for ground tissues. Thus, we

265 recommend avoiding aggressive delipidation when possible except in lipid-rich tissues such as

266 whale skin. For these Sowerby's beaked whale tissues, $\mathrm{C}: \mathrm{N}$ values $<5$ indicate lipids have been

267 removed while preserving the relative abundance of amino acids; we anticipate repeating this

268 analysis on the same tissue types from other whale species would yield comparable results.

269 Lipid content in tissue samples and how the presence of lipids effects $\delta^{13} \mathrm{C}$ is an

270 important consideration when designing animal studies. Our work provides insight into selecting

271 the appropriate delipidation technique, if applicable, for a variety of tissues with varying levels

272 of lipid content. When ample tissue is available and funding permits, we recommend reporting

273 isotope values from both unextracted and chloroform:methanol extracted samples. Researchers

274 would then consider $\delta^{15} \mathrm{~N}$ values from the unextracted sample and $\delta^{13} \mathrm{C}$ from the extracted

275 sample in studies. However, for rare or scarce tissues, or when funding limits processing to one

276 sample, we recommend using cyclohexane for tissues with low or moderate lipid content, and

277 chloroform:methanol for lipid-rich tissues. 
279

280

281

282

283

284

285

286

287

288

289

290

291

292

293

294

295

296

297

298

299

300

301

302

\section{Acknowledgments}

KS was a PhD student funded by the National Museum of Natural History Peter Buck

Fellowship Program. This work was supported by Smithsonian's Museum Conservation Institute Federal and Trust Funds. We thank the Scottish Marine Animal Stranding Scheme for access to the tissue samples used in this study and Nicholas Davison for his helpful guidance and support.

\section{References}

1. Peterson BJ, Fry B. Stable isotopes in ecosystem studies. Annual Review of Ecology and Systematics. 1987;18(1):293-320.

2. Keeling CD. The Suess effect: 13Carbon-14Carbon interrelations. Environment International. 1979;2(4):229-300.

3. Ben-David M, Flaherty EA. Stable isotopes in mammalian research: a beginner's guide. Journal of Mammalogy. 2012;93(2):312-328.

4. Phillips DL, Eldridge PM. Estimating the timing of diet shifts using stable isotopes. Oecologia. 2006;147(2):195-203.

5. Vander Zanden MJ, Clayton MK, Moody EK, Solomon CT, Weidel BC. Stable Isotope Turnover and Half-Life in Animal Tissues: A Literature Synthesis. Plos One. 2015;10(1).

6. Hobson KA. Tracing origins and migration of wildlife using stable isotopes: a review. Oecologia. 1999;120(3):314-326.

7. Cristescu B, Boyce MS. Focusing Ecological Research for Conservation. AMBIO. 2013;42(7):805-815.

8. Post DM, Layman CA, Arrington DA, Takimoto G, Quattrochi J, Montaña CG. Getting to the Fat of the Matter: Models, Methods and Assumptions for Dealing with Lipids in Stable Isotope Analyses. Oecologia. 2007;152(1):179-189. 
303 9. Elliott KH, Roth JD, Crook K. Lipid Extraction Techniques for Stable Isotope Analysis

304 and Ecological Assays. In: Bhattacharya SK, ed. Lipidomics: Methods and Protocols.

305 Vol 1609. Totowa: Humana Press Inc; 2017:9-24.

306 10. West JB, Bowen GJ, Cerling TE, Ehleringer JR. Stable isotopes as one of nature's

307 ecological recorders. Trends in Ecology \& Evolution. 2006;21(7):408-414.

308 11. Elliott KH, Elliott JE. Lipid extraction techniques for stable isotope analysis of bird eggs:

309 Chloroform-methanol leads to more enriched $13 \mathrm{C}$ values than extraction via petroleum $310 \quad$ ether. Journal of Experimental Marine Biology and Ecology. 2016;474:54-57.

311 12. DeNiro M, Epstein S. Mechanism of carbon isotope fractionation associated with lipid $312 \quad$ synthesis. Science. 1977;197(4300):261-263.

313 13. Ryan C, McHugh B, Trueman CN, Harrod C, Berrow SD, O'Connor I. Accounting for 314 the effects of lipids in stable isotope ( $\delta 13 \mathrm{C}$ and $\delta 15 \mathrm{~N}$ values) analysis of skin and blubber 315 of balaenopterid whales. Rapid Communications in Mass Spectrometry. $316 \quad 2012 ; 26(23): 2745-2754$.

317 14. Logan JM, Lutcavage ME. A comparison of carbon and nitrogen stable isotope ratios of 318 fish tissues following lipid extractions with non-polar and traditional 319 chloroform/methanol solvent systems. Rapid Communications in Mass Spectrometry. $320 \quad 2008 ; 22(7): 1081-1086$.

321 15. Bergamo TF, Botta S, Copertino M. Lipid extraction in stable isotope analyses of 322 juvenile sea turtle skin and muscle. Aquatic Biology. 2016;25:1-6.

323 16. Wahl SA, Dauner M, Wiechert W. New tools for mass isotopomer data evaluation in 13C 324 flux analysis: Mass isotope correction, data consistency checking, and precursor 325 relationships. Biotechnology and Bioengineering. 2004;85(3):259-268. 
326 17. Giménez J, Ramírez F, Forero MG, Almunia J, de Stephanis R, Navarro J. Lipid effects

327 on isotopic values in bottlenose dolphins (Tursiops truncatus) and their prey with

328 implications for diet assessment. Marine Biology. 2017;164(6):122.

329 18. Elliott KH, Davis M, Elliott JE. Equations for Lipid Normalization of Carbon Stable $330 \quad$ Isotope Ratios in Aquatic Bird Eggs. PLOS ONE. 2014;9(1):e83597.

331 19. Skinner MM, Martin AA, Moore BC. Is lipid correction necessary in the stable isotope 332 analysis of fish tissues? Rapid Communications in Mass Spectrometry. 2016;30(7):881$333 \quad 889$.

334 20. Taylor GC, Hill JM, Jackson MC, Peel RA, Weyl OLF. Estimating $\delta 15 \mathrm{~N}$ fractionation 335 and adjusting the lipid correction equation using Southern African freshwater fishes. $336 \quad$ PLOS ONE. 2017;12(5):e0178047.

337 21. Logan JM, Jardine TD, Miller TJ, Bunn SE, Cunjak RA, Lutcavage ME. Lipid 338 corrections in carbon and nitrogen stable isotope analyses: comparison of chemical 339 extraction and modelling methods. Journal of Animal Ecology. 2008;77(4):838-846.

340 22. Yurkowski DJ, Hussey NE, Semeniuk C, Ferguson SH, Fisk AT. Effects of lipid 341 extraction and the utility of lipid normalization models on $\delta 13 \mathrm{C}$ and $\delta 15 \mathrm{~N}$ values in 342 Arctic marine mammal tissues. Polar Biology. 2015;38(2):131-143.

343 23. Lesage V, Morin Y, Rioux È, Pomerleau C, Ferguson SH, Pelletier É. Stable isotopes and 344 trace elements as indicators of diet and habitat use in cetaceans: predicting errors related 345 to preservation, lipid extraction, and lipid normalization. Marine Ecology Progress $346 \quad$ Series. 2010;419:249-265. 
347 24. Sweeting CJ, Polunin NVC, Jennings S. Effects of chemical lipid extraction and

348 arithmetic lipid correction on stable isotope ratios of fish tissues. Rapid Communications

349 in Mass Spectrometry. 2006;20(4):595-601.

350 25. Bligh EG, Dyer WJ. A rapid method of total lipid extraction and purification. Canadian 351 Journal of Biochemistry and Physiology. 1959;37(8):911-917.

352 26. Monteiro-Riviere NA, Inman AO, Mak V, Wertz P, Riviere JE. Effect of Selective Lipid 353 Extraction from Different Body Regions on Epidermal Barrier Function. Pharmaceutical $354 \quad$ Research. 2001;18(7):992-998.

355 27. Kojadinovic J, Richard P, Le Corre M, Cosson RP, Bustamante P. Effects of Lipid 356 Extraction on $\delta^{13} \mathrm{C}$ and $\delta^{15} \mathrm{~N}$ Values in Seabird Muscle, Liver and Feathers. Waterbirds: 357 The International Journal of Waterbird Biology. 2008;31(2):169-178.

358 28. Chouvelon T, Chappuis A, Bustamante P, et al. Trophic ecology of European sardine 359 Sardina pilchardus and European anchovy Engraulis encrasicolus in the Bay of Biscay 360 (north-east Atlantic) inferred from delta C-13 and delta N-15 values of fish and identified 361 mesozooplanktonic organisms. J Sea Res. 2014;85:277-291.

362 29. Li Y, Ghasemi Naghdi F, Garg S, et al. A comparative study: the impact of different lipid extraction methods on current microalgal lipid research. Microb Cell Fact. 2014;13:1414.

365 30. Anthony R, Stuart B. Solvent Extraction and Characterization of Neutral Lipids in $366 \quad$ Oocystis sp. Frontiers in Energy Research. 2015;2(64).

367 31. Howa JD, Lott MJ, Chesson LA, Ehleringer JR. Isolation of components of plastic 368 explosives for isotope ratio mass spectrometry. Forensic Chem. 2016;1:6-12. 
369 32. Sarakinos HC, Johnson ML, Zanden MJV. A synthesis of tissue-preservation effects on

370 carbon and nitrogen stable isotope signatures. Canadian Journal of Zoology.

$371 \quad 2002 ; 80(2): 381-387$.

372 33. Javornik J, Hopkins JB, III, Zavadlav S, et al. Effects of ethanol storage and lipids on 373 stable isotope values in a large mammalian omnivore. Journal of Mammalogy.

$374 \quad 2019 ; 100(1): 150-157$.

375 34. Hogsden KL, McHugh PA. Preservatives and sample preparation in stable isotope analysis of New Zealand freshwater invertebrates. New Zealand Journal of Marine and Freshwater Research. 2017;51(3):455-464.

378 35. Kaehler S, Pakhomov EA. Effects of storage and preservation on the d13C and d15N signatures of selected marine organisms. Marine Ecology Progress Series. 2001;219:299-

381 36. R: A language and environment for statistical computing [computer program]. Version 382 3.5.0. Vienna, Austria: R Foundation for Statistical Computing; 2018.

383 37. RStudio: Integrated Development for $R$ [computer program]. Version 1.0.453. Boston, 384 Massachusetts: RStudio Inc; 2016.

385 38. McConnaughey T, McRoy CP. Food-Web structure and the fractionation of Carbon 386 isotopes in the bering sea. Marine Biology. 1979;53(3):257-262. 
$8 \quad$ Table 1.

7 Mean $( \pm \mathrm{SD}) \delta^{13} \mathrm{C}, \delta{ }^{15} \mathrm{~N}$, and $\mathrm{C}: \mathrm{N}$ values of chloroform:methanol and cyclohexane delipidated Sowerby's

J beaked whale tissues. $P$ values are for paired Wilcoxon tests to evaluate difference in values post extraction 1 method in subsamples of the same tissue sample.

\begin{tabular}{|c|c|c|c|c|c|c|c|}
\hline & \multirow[b]{2}{*}{ Tissue } & \multirow[b]{2}{*}{$n$} & \multicolumn{2}{|c|}{ Chloroform:methanol } & \multicolumn{2}{|c|}{ Cyclohexane } & \multirow[b]{2}{*}{$P$} \\
\hline & & & Mean & SD & Mean & SD & \\
\hline \multirow[t]{4}{*}{$\delta^{13} \mathrm{C}$} & Kidney & 18 & -17.7 & 0.76 & -18.0 & 0.82 & 0.014 \\
\hline & Liver & 17 & -17.8 & 0.62 & -18.2 & 0.84 & 0.001 \\
\hline & Muscle & 18 & -18.1 & 1.08 & -18.3 & 0.90 & 0.081 \\
\hline & Skin & 24 & -19.1 & 0.93 & -19.5 & 1.15 & 0.007 \\
\hline \multirow[t]{4}{*}{$\delta^{15} \mathrm{~N}$} & Kidney & 18 & 13.3 & 0.80 & 13.1 & 0.72 & 0.012 \\
\hline & Liver & 17 & 13.2 & 0.88 & 13.2 & 0.85 & 0.712 \\
\hline & Muscle & 18 & 12.6 & 0.82 & 12.7 & 0.96 & 0.865 \\
\hline & Skin & 24 & 12.7 & 0.94 & 12.6 & 0.91 & 0.331 \\
\hline \multirow[t]{4}{*}{$\mathrm{C}: \mathrm{N}$} & Kidney & 18 & 3.2 & 0.10 & 3.3 & 0.15 & 0.002 \\
\hline & Liver & 17 & 3.2 & 0.10 & 3.4 & 0.20 & $<0.001$ \\
\hline & Muscle & 18 & 3.2 & 0.22 & 3.3 & 0.32 & 0.899 \\
\hline & Skin & 24 & 3.8 & 0.45 & 4.1 & 0.69 & 0.014 \\
\hline
\end{tabular}




\section{$4 \quad$ Table 2.}

5 Mean $( \pm \mathrm{SD}) \delta^{13} \mathrm{C}, \delta^{15} \mathrm{~N}$, and $\mathrm{C}: \mathrm{N}$ values for unextracted, chloroform:methanol lipid extracted, and

6 cyclohexane lipid extracted Sowerby's beaked whale tissues. $P$ values pertain to paired Wilcoxon tests

7 comparing mean values pre and post extraction to evaluate the magnitude of change each extraction method

8 has on values.

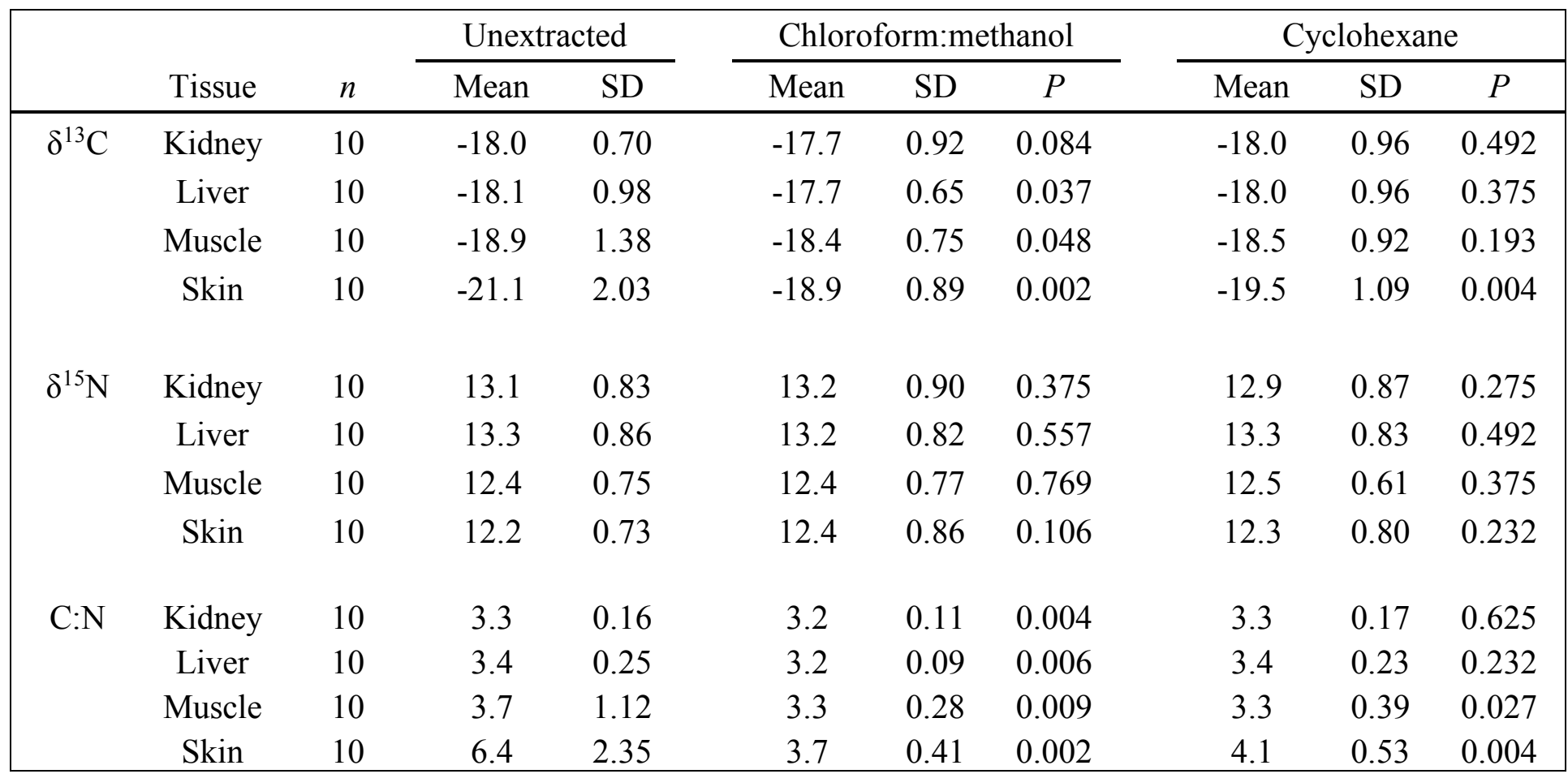


402 Mean $( \pm \mathrm{SD}) \Delta^{13} \mathrm{C}, \Delta{ }^{15} \mathrm{~N}$, and $\Delta \mathrm{C}: \mathrm{N}$ values between delipidated and unextracted Sowerby's beaked whale tissues (extracted value - unextracted

403 value). $P$ values pertain to unpaired Wilcoxon tests to evaluate difference in the change to isotope values by delipidation method.

404

\begin{tabular}{|c|c|c|c|c|c|c|c|}
\hline & \multirow[b]{2}{*}{ Tissue } & \multirow[b]{2}{*}{$n$} & \multicolumn{2}{|c|}{ Chloroform:methanol } & \multicolumn{2}{|c|}{ Cyclohexane } & \multirow[b]{2}{*}{$P$} \\
\hline & & & Mean & SD & Mean & $\mathrm{SD}$ & \\
\hline \multirow[t]{4}{*}{$\Delta^{13} \mathrm{C}$} & Kidney & 10 & 0.7 & 0.53 & 0.0 & 0.39 & 0.123 \\
\hline & Liver & 10 & 0.4 & 0.48 & 0.1 & 0.45 & 0.143 \\
\hline & Muscle & 10 & 0.5 & 0.85 & 0.3 & 0.63 & 0.529 \\
\hline & Skin & 10 & 2.2 & 1.39 & 1.6 & 1.16 & 0.248 \\
\hline \multirow[t]{4}{*}{$\Delta \delta^{15} \mathrm{~N}$} & Kidney & 10 & 0.2 & 0.48 & -0.2 & 0.49 & 0.315 \\
\hline & Liver & 10 & -0.1 & 0.36 & -0.1 & 0.31 & 1.000 \\
\hline & Muscle & 10 & 0.1 & 0.41 & 0.1 & 0.20 & 0.853 \\
\hline & Skin & 10 & 0.2 & 0.26 & 0.1 & 0.32 & 1.000 \\
\hline \multirow[t]{4}{*}{$\Delta \mathrm{C}: \mathrm{N}$} & Kidney & 10 & -0.1 & 0.11 & 0.0 & 0.10 & 0.075 \\
\hline & Liver & 10 & -0.3 & 0.19 & -0.1 & 0.14 & 0.015 \\
\hline & Muscle & 10 & -0.4 & 0.94 & -0.4 & 0.74 & 0.739 \\
\hline & Skin & 10 & -2.7 & 2.26 & -2.3 & 2.17 & 0.529 \\
\hline
\end{tabular}

405 